\title{
Disparitas penerbitan Surat Izin Mengemudi sebagai pemenuhan hak bagi penyandang tunarungu
}

\author{
Publishing disparity of driving license as a meeting of right for tunarungu \\ persons
}

\author{
Dini Annisa Rahmat \\ Program Studi Magister Kajian Ilmu Kepolisian, Sekolah Pascasarjana, Universitas Airlangga \\ Surabaya, 60286, Jawa Timur, Indonesia \\ E-mail: dini.annisa.rahmat-2016@pasca.unair.ac.id
}

\begin{abstract}
Abstrak
Disparitas kebijakan pada tiap-tiap wilayah Polrestabes, Polresta atau Polres dalam penerbitan SIM untuk penyandang tuna rungu diasumsikan oleh penulis terjadi karena tidak adanya kesepahaman yang sama terhadap bagaimana kebijakan penerbitan SIM bagi penyandang disabilitas khususnya bagi penyandang tuna rungu, tidak adanya aturan teknis lebih lanjut serta resiko yang nantinya didapatkan oleh Polrestabes, Polresta atau Polres yang telah menerbitkan SIM jika nantinya penyandang tuna rungu tersebut mengalami kecelakaan dikarenakan kekurangan responsifnya mereka dalam mendengar, merupakan salah satu kekhawatiran bagi Satpas untuk menerbitkan SIM bagi penyandang tuna rungu. Penelitian ini bertujuan untuk mengetahui disparitas penerbitan surat izin mengemudi sebagai pemenuhan hak bagi penyandang tunarungu. Metode yang digunakan adalah deskriptif analitis. Hasil penelitian menunjukkan bahwa Satpas di Polda Metro Jaya Jakarta menafsirkan pasal 80 huruf (e) UULLAJ dan Pasal 7 huruf (e) Perkap No. 9 Tahun 2012 adalah dengan menggunakan penafsiran secara a contrario dan penafsiran Gramatikal. Satpas Polresta Denpasar menggunakan penafsiran teleologis dan penafsiran ekstensif untuk memaknai pasal tersebut. Sedangkan kebijakan Polresta Mojokerto Kota yang tidak menerbitkan SIM jenis apapun bagi pemohon dengan kondisi jasmani mengalami cacat pendengaran (tuna rungu) adalah karena adanya tafsiran restriktif. Pemohon tuna rungu, maka hendaknya dalam perubahan regulasi ataupun usulan adanya pedoman teknis bagi pemohon SIM harus ada kejelasan pendefinisian mengenai penyandang cacat yang dicantumkan dalam ketentuan undang undang atau perkap.
\end{abstract}

Kata kunci: disabilitas; kecelakaan; perubahan; kebijakan

\begin{abstract}
The policy disparity in each Polrestabes, Polresta or Polres area in issuing SIM for deaf people is assumed by the author to occur because there is no common understanding of how the issuance of SIM policy for persons with disabilities especially for persons with hearing impairment, the absence of further technical rules and the risk that will be obtained by the Polrestabes, Polresta or Polres who have issued a SIM if later the deaf suffer an accident due to their lack of responsiveness in hearing, is one of the concerns for Satpas to issue a SIM for deaf people. This study aims to determine the disparity in the issuance of a driver's license as a fulfillment of the rights of persons with hearing impairment. The method used is descriptive analytical. The results showed that the Satpas at the Jakarta Metropolitan Police interpreted article 80 letter (e) UULLAJ and Article 7 letter (e) Perkap No. 9 of 2012 is to use a contrario interpretation and Grammatical interpretation. The Denpasar Police Satpas used teleological interpretation and extensive interpretation to interpret the article. Whereas the policy of the Kota Mojokerto Police who did not issue any type of SIM for applicants with physical conditions hearing impaired (hearing impaired) was due to a restrictive interpretation. Applicants with hearing impairment, then in changes to regulations or proposals for technical guidelines for SIM applicants, there must be a clear definition of the person with disabilities stated in the statutory or statutory provisions.
\end{abstract}

Keywords: disability; accident; change; Policy

\section{Pendahuluan}

Salah satu instansi pemerintah yang diwajibkan melaksanakan fungsi pelayanan publik adalah Kepolisian Republik Indonesia. Pelayanan publik yang menjadi kewenangan Kepolisian diantaranya adalah dalam hal penerbitan Surat Izin Mengemudi (SIM) (Agustino 2012). Diatur dalam Peraturan Kepala Kepolisian Negara Republik Indonesia Nomor 9 Tahun 2012 tentang Surat Izin Mengemudi (Perkap No. 9 Tahun 2012) Pasal 52 ayat (2) tentang Surat Izin Mengemudi menyebutkan bahwa yang 
berwenang dalam melakukan penerbitan SIM kepada masyarakat adalah Kepala Kepolisian di setiap wilayah masing-masing dan didelegasikan kepada Kepala Satuan Lalu Lintas. Pelayanan penerbitan SIM merupakan salah satu unsur pelayanan dasar administratif yang penting Tachjan (2006). Dengan SIM, seseorang dianggap sudah memiliki hak dan kewajiban dalam mengendarai kendaran bermotor sehingga dalam berkendara haruslah selalu mentaati peraturan yang berlaku. SIM merupakan bukti administratif bahwa seseorang tersebut sudah terikat oleh hukum, terutama hukum dalam berkendaraan. Isu disabilitas juga mendapat perhatian khusus bagi intitusi kepolisian untuk menerapkan kesetaraan dalam mendapatkan kesempatan yang sama untuk memperoleh SIM (Steinhardt \& Wishart 2006; Abdullah 2019; Wiratama 2018; Syafiie 2014; Golbran 2010; Kuniawan 2019; Tohari 2014).

Berdasarkan Pasal 80 huruf (e) Undang-undang Nomor 22 Tahun 2009 tentang Lalu Lintas dan Angkutan Jalan (UU LLAJ) menyebutkan bahwa Surat Izin Mengemudi D berlaku untuk mengemudikan kendaraan khusus bagi penyandang cacat (Agustino 2012). Aturan tersebut diturunkan lagi dalam Pasal 7 huruf (e) Perkap No. 9 Tahun 2012 yang menyebutkan adanya SIM khusus yakni SIM D yang diterbitkan khusus dan berlaku untuk mengemudi Ranmor Khusus bagi penyandang cacat. Kebijakan tiap-tiap wilayah Polrestabes, Polresta atau Polres dalam penerbitan SIM untuk penyandang disabilitas terdapat disparitas atau perbedaan dalam praktiknya. Disparitas pemenuhan hak bagi penyandang disparitas dalam penerbitan SIM ini terjadi khususnya bagi para penyandang tunarungu. Disparitas pemenuhan hak untuk penerbitan SIM bagi penyandang tuna rungu terdiri dari 3 (tiga) macam yakni Satpas menerbitkan SIM A atau C, Satpas menerbitkan SIM D dan Satpas tidak menerbitkan sama sekali. Disparitas kebijakan pada tiap-tiap wilayah Polrestabes, Polresta atau Polres dalam penerbitan SIM untuk penyandang tuna rungu diasumsikan oleh penulis terjadi karena tidak adanya kesepahaman yang sama terhadap bagaimana kebijakan penerbitan SIM bagi penyandang disabilitas khususnya bagi penyandang tuna rungu, tidak adanya aturan teknis lebih lanjut serta resiko yang nantinya didapatkan oleh Polrestabes, Polresta atau Polres yang telah menerbitkan SIM jika nantinya penyandang tuna rungu tersebut mengalami kecelakaan dikarenakan kekurangan resonsifnya mereka dalam mendengar, merupakan salah satu kekhawatiran bagi Satpas untuk menerbitkan SIM bagi penyandang tuna rungu.

Konsepsi HAM, tidak satupun yang secara eksplisit mengatur tentang definisi HAM, sebagaimana dikemukakan oleh Gudmundur Alfredsson (2002) : "What is human rights? None of the International human rights instruments expressly define what human rights is". Namun untuk mencermati mengenai hakekat HAM, setidaknya dapat diperoleh dari materi yang terdapat dalam Universal Declaration of Human Rights yang diterima dan diumumkan oleh Majelis Umum PBB pada tanggal 10 Desember 1948 melalui Resolusi 217 A (III), yaitu terdiri atas Mukadimah dan Pasal 1 sampai dengan Pasal 30. Ditentukan dalam Pasal 1 "All human beings are born free and equal in dignity and rights. They are endowed with reason and conscience and should act towards one another in a spirit of brotherhood" Dari ketentuan tersebut ada beberapa hal yang dapat digarisbawahi, yaitu: Semua orang dilahirkan merdeka, semua orang memiliki martabat dan hak-hak yang sama, tidak dapat dicabut dari semua anggota keluarga manusia, semua orang dikaruniai akal dan hati nurani, semua orang hendaknya bergaul satu sama lain dalam persaudaraan.

Konsep penyandang disabilitas, beradasarkan Pasal 1 UU No. 8 Tahun 2016 bahwa enyandang disabilitas adalah setiap orang yang mengalami keterbatasan fisik, intelektual, mental, dan/atau sensorik dalam jangka waktu lama yang dalam berinteraksi dengan lingkungan dapat mengalami hambatan dan kesulitan untuk berpartisipasi secara penuh dan efektif dengan warga negara lainnya berdasarkan kesamaan hak (Infodatin 2014; Rofah 2011; Suharmini 2009). Pelaksanaan dan pemenuhan hak penyandang disabilitas berasaskan pada: Penghormatan terhadap martabat, otonomi individu, tanpa diskriminasi, partisipasi penuh, keragaman manusia dan kemanusiaan, kesamaan kesempatan, kesetaraan, aksesibilitas, kapasitas yang terus berkembang dan identitas anak, inklusif, dan perlakuan khusus dan perlindungan lebih.

Tunarungu sebagai salah satu penyandang disabilitas, untuk melaksanakan perintah konstitusi dan konvensi yang telah mengikat, maka dikeluarkan peraturan untuk melindungi hak penyandang 
disabilitas untuk mendapatkan perlakuan yang sama pada pelayanan publik, yakni terdapat pada Undang-Undang Nomor 8 Tahun 2016 tentang Penyandang Disabilitas. Penyandang disabilitas memperoleh perlakuan khusus dimaksudkan sebagai upaya perlindungan dari kerentanan terhadap berbagai pelanggaran hak asasi manusia, kekurangan yang dialami tidak menjadi alasan untuk mengurangi hak mereka dalam memperoleh hak hidup dan hak mempertahankan kehidupan. Pasal 4 UU No. 8 Tahun 2016, memberikan kualifikasi mengenai ragam Penyandang Disabilitas meliputi: fisik, intelektual, mental dan sensorik.

Yang dimaksud dengan "Penyandang Disabilitas sensorik" berdasarkan penjelasan UU No. 8 Tahun 2016 adalah terganggunya salah satu fungsi dari panca indera, antara lain disabilitas netra, disabilitas rungu, dan/atau disabilitas wicara. Secara umum kondisi tuna rungu diartikan sebagai kondisi seseorang yang tidak dapat mendengar. Tidak dapat mendengar tersebut dapat dimungkinkan kurang dengar atau tidak mendengar sama sekali. Secara fisik, tuna rungu tidak berbeda dengan dengar pada umumnya, sebab orang akan mengetahui bahwa menyandang ketuna runguan pada saat berbicara, tersebut berbicara tanpa suara atau dengan suara yang kurang atau tidak jelas artikulasinya, atau bahkan tidak berbicara sama sekali, tersebut hanya berisyarat. Agar dapat diperoleh pengertian yang lebih jelas tentang tuna rungu, berikut ini dikemukakan definisi tuna rungu oleh beberapa ahli.

\section{Metode Penelitian}

Jenis penelitian yang digunakan adalan penelitian normatif-empiris. Penelitian hukum normatifempiris adalah penelitian hukum mengenai pemberlakuan ketentuan hukum normatif (kodifikasi, undang-undang atau aturan dibawah perundangan) secara in action pada setiap peristiwa hukum tertentu yang terjadi dalam masyarakat.

Penelitian ini menggunakan metode deskriptif analitis adalah penelitian yang menekankan pada penggambaran suatu peristiwa yang terjadi, dengan perkataan lain penelitian deskripsi mengambil masalah-masalah, yang bersifat aktual, sebagaimana adanya pada saat penelitian diadakan. Sementara itu, sumber data dan informasi yang digunakan dalam penelitian ini adalah data primer dan sekunder. Sumber data primer dalam ini diperoleh antara lain dengan wawancara kepada Pamin SIM Polda Metro Jaya yaitu Ipda Efensi, Baur SIM Polres Mojokerto Kota yaitu Aiptu Sutikno, Baur SIM Polresta Denpasar yaitu Bripka Sudarsana. Untuk data sekunder, selain kata-kata dan tindakan sebagai sumber data utama diperlukan juga data-data tambahan seperti dokumen dan lain-lain sebagai sumber data sekunder. Teknik penelitian yang penulis gunakan untuk mengumpulkan data dalam penelitian ini adalah wawancara, observasi dan telaah dokumen.

\section{Hasil dan pembahasan}

\section{Dasar pertimbangan penerbitan Surat ljin Mengemudi (SIM) terhadap penyandang tuna rungu}

Persoalan mengenai kebijakan penerbitan SIM adalah adanya disparitas dalam kebijakan penerbitan SIM bagi pemohon penyandang tuna rungu yang memberikan hasil akhir berupa 3 kebijakan yang berbeda (disparitas) yakni Satpas menerbitkan SIM A atau C, Satpas menerbitkan SIM D dan Satpas tidak menerbitkan sama sekali. Pangkal persoalan dalam terjadinya disparitas adalah penafsiran yang berbeda pada tiap-tiap Satpas terhadap ketentuan-ketentuan yang mengatur penerbitan SIM untuk penyandang disabilitas dalam Pasal 80 huruf (e) UU LLAJ serta Pasal 7 huruf (e) Perkap No. 9 Tahun 2012. Secara garis besar, Pasal 80 huruf (e) UULLAJ menyebutkan bahwa Surat Izin Mengemudi D berlaku untuk mengemudikan kendaraan khusus bagi penyandang cacat. Aturan tersebut diturunkan lagi dalam Pasal 7 Perkap No. 9 Tahun 2012 yang menyatakan bahwa SIM D, berlaku untuk mengemudi Ranmor Khusus bagi penyandang cacat.

Polda Metro Jaya, merupakan Satpas yang menerbitkan SIM A atau C bagi pemohon dengan kondisi tuna rungu. Mengenai pertimbangan kebijakan tersebut dipaparkan oleh Pamin SIM Polda Metro Jaya: Tuna rungu memang termasuk penyandang cacat, namun mereka tidak menggunakan kendaraan 
khusus seperti yang disebutkan dalam Pasal 80 huruf (e) UU LLAJ dan Pasal 7 huruf (e) Perkap No. 9 Tahun 2012 tentang SIM "Surat Izin Mengemudi D berlaku untuk mengemudikan kendaraan khusus bagi penyandang cacat. Jadi dengan kata lain mereka berhak untuk mendapatkan SIM A/C. Mengenai kebijakan ini jelas tidak ada unsur diskresi. Jadi didasarkan oleh tidak termasuknya penyandang tuna rungu dalam ketentuan "pengemudi dengan kendaraan khusus," sehingga SIM D bukan hak mereka tetapi SIM A/C lah yang menjadi hak mereka untuk diterbitkan jenis SIM tersebut.

Berdasarkan analisis penulis dari wawancara yang telah dilakukan maka aturan dalam pasal 80 huruf (e) UULLAJ dan Pasal 7 huruf (e) Perkap No. 9 Tahun 2012 ditafsirkan dengan menggunakan penafsiran secara a contrario. Penafsiran a contrario (menurut peringkaran), ialah suatu cara menafsirkan undang-undang yang didasarkan pada perlawanan pengertian antara soal yang dihadapi dan soal yang diatur dalam suatu pasal undang-undang.

Metode a Contrario yang digunakan untuk menyimpulkan Pasal 80 huruf (e) UULLAJ dan Pasal 7 huruf (e) Perkap No. 9 Tahun 2012, jika disusun secara silogisme alternatif secara a contrario akan menghasilkan rumusan :

Premis 1 : Semua penyandang cacat yang memenuhi persyaratan kelayakan mengemudi dari dokter yang tidak mengemudikan kendaraan khusus, tidak diterbitkan SIM D melainkan SIM A/C.

Premis 2 : Penyandang tuna rungu yang memenuhi persyaratan kelayakan mengemudi dari dokter tidak mengemudikan kendaraan khusus

Kesimpulan : Penyandang tuna rungu yang memenuhi persyaratan kelayakan mengemudi dari dokter tidak diterbitkan SIM D melainkan SIM A/C.

Jadi, berdasarkan analisis penulis, penafsiran a contrario yang digunakan Satpas Polda Metro Jaya dalam menerjemahkan Pasal 80 huruf (e) UULLAJ dan Pasal 7 huruf (e) Perkap No. 9 Tahun 2012 merupakan dasar logika hukum untuk melakukan penerbitan SIM A/C bagi Penyandang tuna rungu yang telah memenuhi persyaratan kelayakan mengemudi dari dokter.

Selain penafsiran a contrario, dalam memahami pasal Pasal 80 huruf (e) UULLAJ dan Pasal 7 huruf (e) Perkap No. 9 Tahun 2012 diketahui pula bahwa digunakan penafsiran gramatikal sebagai metode pemahamannya. Mengenai Dipaparkan oleh Pamin SIM Polda Metro Jaya yang menyatakan bahwa: Kalimat di pasal tersebut adalah kalimat yang tak terpisahkan yakni menunjuk pada jenis SIM yakni SIM D, kalimat berikutnya menunjuk pada jenis ranmornya yakni ranmor khusus artinya ranmor yang sudah dimodifikasi sesuai penggunanya, terakhir kalimat dalam pasal tersebut juga menunjuk pada subyek pemohonnya yakni penyandang cacat yang tentunya menggunakan kendaraan khusus sebagai alat transportasinya.

Dalam kalimat di Pasal 80 huruf (e) UU LLAJ dan Pasal 7 huruf (e) Perkap No. 9 Tahun 2012 yang pada intinya menyatakan bahwa "Surat Izin Mengemudi D berlaku untuk mengemudikan kendaraan bermotor khusus bagi penyandang cacat", secara gramatikal dengan pendekatan noscitur a socis atau arti suatu perkataan harus dinilai dari ikatannya dalam kumpulan-kumpulannya, maka jika dianalisis dari Pola ikatan kalimatnya maka kalimat dalam pasal tersebut termasuk "kalimat majemuk bertingkat" dengan menggunakan "konjungsi subordinatif tujuan". Kalimat majemuk bertingkat ialah kalimat yang terjadi atas beberapa kalimat tunggal yang kedudukannya tidak setara/ sederajat, yakni yang satu menjadi bagian yang lain Salah satu klausa atau anak kalimat tidak dapat berdiri sendiri. Klausa yang satu merupakan induk kalimat, dan klausa yang lain merupakan anak kalimat. Kedua klausa itu biasanya dihubungkan dengan konjungsi subordinatif.

Ciri dari kalimat majemuk bertingkat ini adalah jika dipisahkan tidak memiliki makna. Artinya di sini dalam membaca Pasal 80 huruf (e) UU LLAJ dan Pasal 7 huruf (e) Perkap No. 9 Tahun 2012 haruslah dibaca dalam satu kesatuan kalimat tanpa bisa dipisahkan agar memiliki makna yang benar sesuai dengan tujuan dalam penyusunan kalimat tersebut. Lebih khusus lagi, untuk menunjukkan bentuk kalimat majemuk bertingkat yang digunakan sebagai pola penyusunan pasal-pasal tersebut maka dapat 
diketahui dari 2 unsur "konjungsi subordinatif tujuan" dalam kalimat tersebut yakni dengan adanya kata "untuk" serta kata "bagi".

Kalimat dalam pasal di atas menggunakan "konjungsi subordinatif tujuan" ditandai dengan kata hubung "untuk" serta "bagi" yang berfungsi menyatakan hubungan tujuan dilakukannya tindakan sebagaimana disebutkan pada induk kalimat. Konjungsi subordinatif tujuan dengan kata "untuk" serta "bagi" yang mana kata "untuk" tersebut menghubungkan klausa yang menyatakan tujuan peruntukan SIM D yakni lisensi mengemudi kendaraan bermotor khusus yang kemudian dirangkai lagi dengan kata "bagi" yang menyatakan tujuan final dari obyek peruntukan SIM D yakni bagi penyandang cacat. Jadi bisa dimaknai bahwa jenis-jenis SIM termasuk SIM D adalah suatu jenis lisensi yang bukan merujuk bagi subyeknya (si pengemudi) tetapi lebih pada obyek atau jenis kendaraan yang dikendarai oleh subyek (pengemudi) tersebut.

Pasal tersebut sudah seharusnya dimaknai dengan utuh tidak dipotong perkalimatnya sehingga jika kalimat tidak dipisahkan maka makna yang sebenarnya akan dapat diketahui. Artinya jika ditarik maknanya maka akan memberikan pengertian bahwa SIM D diperuntukkan untuk penyandang cacat yang menggunakan kendaraan khusus yang dalam hal ini pemakai kendaraan khusus hanya seorang tuna daksa bukan tuna rungu. Sehingga berdasarkan analisis tersebut penulis berkesimpulan bahwa kebijakan yang diterapkan oleh Satpas Polda Metro Jaya dengan memberikan SIM A/C pada pemohon tuna rungu yang memenuhi persyaratan dari dokter untuk mengemudi, adalah mendasarkan penafsirannya pada penafsiran a contrario serta penafsiran gramatikal.

Analisis penulis berikutnya adalah pada kebijakan Satpas Polresta Denpasar dalam pengajuan SIM oleh penyandang tuna rungu terutama dikaitkan dengan landasan kebijakan yang lahir dari penafsiran terhadap Pasal 80 huruf (e) UU LLAJ dan Pasal 7 huruf (e) Perkap No. 9 Tahun 2012. Di Satpas ini pemohon tuna rungu yang mengajukan SIM akan diterbitkan SIM D. Berdasarkan hasil wawancara penulis dengan Bripka Sudarsana, mengenai landasan penerbitan SIM D bagi tuna rungu di Satpas Polresta Denpasar didapatkan hasil sebagai berikut: Isi Pasal 80 huruf (e) UU LLAJ yang berbunyi "Surat Izin Mengemudi D berlaku untuk mengemudikan kendaraan khusus bagi penyandang cacat"; dan Pasal 7 huruf (e) Perkap No 9 Tahun 2012 yang juga menyatakan "SIM D, berlaku untuk mengemudikan Ranmor Khusus bagi penyandang cacat", karena tuna rungu merupakan salah satu dari penyandang cacat. Mengenai penyebutan pasal bahwa peruntukan SIM D adalah untuk disabilitas pengguna "kendaraan khusus", ini tidakkah ini kontradiktif dengan penyandang tuna rungu karena Tuna Rungu dalam mengendarai ranmor memang tidak menggunakan kendaraan khusus, namun setiap mereka mengendarai ranmor di mana mereka wajib menggunakan alat bantu pendengaran demi keselamatan dirinya dan pengguna jalan artinya ke khususan ini bisa diberlakukan untuk penyandang tuna rungu yang diwajibkan memakai alat khusus pula dalam berkendara yakni alat bantu pendengaran.

Berdasarkan pendapat tersebut dari analisis penulis didapatkan suatu simpulan bahwa penafsiran Pasal 80 huruf (e) UU LLAJ dan Pasal 7 huruf (e) Perkap No. 9 Tahun 2012 dilakukan menggunakan penafsiran penafsiran teleologis dan penafsiran ekstensif. Untuk analisis pertama yakni penafsiran teleologis. Penafsiran ini merupakan penafsiran dengan mengingat maksud dan tujuan dibuatnya undang-undang itu. Jadi dengan menggunakan logika penafsiran teleologis, penerbitan SIM D sebagaimana diatur dalam Pasal 80 huruf (e) UU LLAJ tidak bisa dibatasi pada penyandang tuna daksa saja tetapi tuna rungu juga harus diakomodir sebagaimana prinsip asas sebagai semangat yang terkandung dalam Pasal tersebut. Pendapat ini sebagaimana dipaparkan oleh Rahardjo (2006) bahwa setiap aturan perundangan pasti memiliki ide atau pikiran yang hendak dikemukakan sebagai 'semangat' dari suatu peraturan perundangan. Maka setiap penentu kebijakan yang akan melaksanakan perintah perundangan wajib melakukan usaha untuk menggali "semangat" dalam peraturan tersebut yang dilakukan salah satunya dalam bentuk interpretasi atau penafsiran.

Penafsiran selanjutnya berdasarkan apa yang disampaikan dalam wawancara dengan Bripka Sudarsana mengenai kalimat "untuk mengemudikan Ranmor khusus" sebagaimana ada Pasal 80 huruf (e) UU LLAJ dan Pasal 7 huruf (e) Perkap No. 9 Tahun 2012, disimpulkan dari hasil wawancara tersebut 
bahwa kalimat tersebut bisa dikesampingkan karena penyandang tuna rungu dalam mengendarai ranmor memang tidak menggunakan kendaraan khusus, tetapi mereka diwajibkan menggunakan alat khusus yakni alat bantu pendengaran sebagaimana rekomendasi dari dokter yang mengeluarkan rekomendasi untuk permohonan SIM D yang diajukannya. Kendaraan khusus tersebut merupakan sarana penunjang dari pengemudi untuk "menyempurnakan" kondisinya sehingga tercipta kenyamanan dan keamanan mengemudi sebagaimana "alat bantu khusus pendengaran" yang diwajibkan pada pengemudi dengan kondisi tuna rungu.

Berdasarkan analisis penulis, metode penafsiran yang dilakukan dalam hal mempersepsikan "alat bantu khusus pendengaran" sebagai suatu sarana bagi pengemudi sebagaimana maksud yang terkandung dalam "kendaraan khusus" adalah penafsiran dengan metode penafsiran ekstensif. Jadi dengan penafsiran ekstensif, "kendaraan bermotor khusus" tidak bisa dimaknai secara harfiah saja. Tetapi harus dimaknai sebagai suatu "sarana" karena semangat dari pasal tersebut adalah untuk legalisasi penyandang cacat dalam memperoleh SIM. Jadi sangat sempit pengertiannya jika hanya dimaknai SIM D tersebut untuk pemilik kendaraan khusus. Tetapi harus dimaknai pengertiannya bahwa pemilik SIM D juga berlaku bagi penyandang cacat yang menggunakan "sarana khusus" yang menutup kekurangannya dalam mengemudi. Sarana tersebut yang bagi penyandang tuna rungu adalah alat bantu dengar.

Selanjutnya akan penulis bahas mengenai kebijakan di Satpas Polresta Mojokerto terkait kebijakannya yang tidak memberikan izin sama sekali untuk penderita tuna rungu. Berdasarkan wawancara Baur SIM Polresta Mojokerto Aiptu Sutikno menjelaskan mengenai kebijakan penerbitan SIM bagi penyandang tuna rungu yang menyatakan bahwa: Penderita tuna rungu merupakan seseorang yang memiliki kekurangan dalam hal pendengaran, dan kesehatan pendengaran merupakan salah satu persyaratan kesehatan yang harus dimiliki seseorang untuk mengurus penerbitan SIM sebagai legalitas seseorang untuk bisa mengendarai ranmor di jalan. Akan sangat membahayakan keselamatan bila tuna rungu mengendarai kendaraan dan tidak bisa mendengar bila ada klakson dari kendaraan lain. Sebagaimana seseorang yang normal pun namun jika dalam mengendarai kendaraan tidak memperhatikan keamanan dan keselamatan berlalu lintas seperti memakai headset atau memodifikasi kendaraannya hingga berkurangnya kedapan suara dalam kabin, mereka merupakan salah satu pelanggar lalu lintas, dan polisi berhak serta berwenang untuk melakukan tindakan.

Dari wawancara tersebut diketahui bahwa tidak adanya pertimbangan sama sekali dalam penerbitan SIM termasuk tidak adanya alternatif mengeluarkan SIM D karena adanya kekurangan diri si pemohon tersebut yakni dalam masalah pendengaran yang dikhawatirkan saat penyandang tuna rungu mengendarai kendaraan bermotor maka ia tidak dapat mendengar suara klakson dari pihak pengendara lain sebagai tanda perhatian/isyarat. Hal tersebut dikhawatirkan dapat membahayakan dirinya dan pengguna jalan lain.

Berdasarkan analisis penulis, maka kebijakan Polresta Mojokerto Kota yang tidak menerbitkan SIM jenis apapun bagi pemohon dengan kondisi jasmani mengalami cacat pendengaran (tuna rungu) adalah karena adanya tafsiran restriktif dalam logikanya untuk memahami Pasal 80 huruf (e) UU LLAJ dan Pasal 7 huruf (e) Perkap No. 9 Tahun 2012. Penafsiran restriktif, ialah penafsiran dengan membatasi (mempersempit) arti kata-kata dalam peraturan itu. Karena resiko yang besar terhadap bahayanya tuna rungu maka penafsiran resktriktif adalah tepat dilakukan oleh Polres Mojokerto Kota.

\section{Solusi terhadap terjadinya disparitas dalam kebijakan penerbitan Surat ljin Mengemudi}

Kontruksi bahasa hukum yang ada selama ini terkadang sulit dipahami. Bahasa hukum cenderung panjang lebar, tidak jelas, multi tafsir, serta menggambarkan bahwa bahasa hukum itu berbeda dari ucapan-ucapan biasa/umum. Hal ini terjadi karena banyak ahli hukum yang beranggapan bahwasanya hukum itu punya bahasa tersendiri, yang berbeda dengan bahasa masyarakat. Padahal apabila mengacu pendapatnya Hamid S. Attamimi yang menyatakan bahwa bahasa hukum dalam peraturan perundangundangan adalah tetap bahasa Indonesia sehingga tetap tunduk pada kaidah-kaidah bahasa Indonesia yang umum dan baku. Hal senada juga disampikan oleh Jimly (2006) yang menyatakan bahwa bahas 
hukum dalam peraturan perundang-undangan tunduk kepada kaidah-kaidah bahasa Indonesia yang baik dan benar, baik yang menyangkut pembentukan kata, penyusunan kalimat, teknik penulisan, maupun penulisan ejaan dan tanda bacanya, dengan corak tersendiri yaitu mempunyai ciri-ciri kejelasan pengertian, kejernian dan kelugasan perumusan, kebakuan, keserasian, dan ketaat-asasan dalam penggunaan kata-kata sesuai dengan kebutuhan hukum yang dihadapi.

Dengan demikian, bahasa hukum peraturan perundang-undangan tetaplah bahasa Indonesia, sehingga tidak seharusnya masyarakat mengalami kesulitan dalam memahami peraturan perundang-undangan. Tergantung para pembentuk peraturan perundang-undangan mampu tidak menyusun peraturan perundang-undangan dengan bersandar pada kaidah bahasa Indonesia yang baik dan benar, tentunya tidak mengenyampingkan substansi hukumnya yang hendak dirumuskan dalam peraturan itu. Jika ditelaah lebih lanjut penulis berikan contoh isi dalam Pasal 80 huruf (e) UULLAJ yang menyebutkan: "Surat Izin Mengemudi D berlaku untuk mengemudikan kendaraan khusus bagi penyandang cacat." Isi pasal tersebut jika ditelaah sebagaimana aturan dalam Undang-undang Nomor 12 Tahun 2011 tentang Pembentukan Peraturan Perundang-undangan, maka asas "kejelasan umum" tidak terdapat dalam pasal tersebut. Disebutkan dalam Pasal 5 UU No. 12 Tahun 2011 bahwa dalam membentuk Peraturan Perundang-undangan harus dilakukan berdasarkan pada asas Pembentukan Peraturan Perundang-undangan yang baik, yang meliputi: kejelasan tujuan; kelembagaan atau pejabat pembentuk yang tepat; kesesuaian antara jenis, hierarki, dan materi muatan; dapat dilaksanakan; kedayagunaan dan kehasilgunaan; kejelasan rumusan; dan. keterbukaan"

Asas "kejelasan rumusan" adalah bahwa setiap peraturan perundang-undangan harus memenuhi persyaratan teknis penyusunan peraturan perundang-undangan, sistematika dan pilihan kata atau terminologi, serta bahasa hukumnya jelas dan mudah dimengerti, sehingga tidak menimbulkan berbagai macam interpretasi dalam pelaksanaannya.

Multi tafsirnya pasal tentang penerbitan SIM D sebagaimana dalam Pasal 80 huruf (e) UULLAJ dan Pasal 7 huruf (e) Perkap No. 9 Tahun 2012 tersebut adalah dikarenakan tidak adanya deskripsi yang jelas mengenai penyandang cacat di bagian ketentuan umum dari undang-undang tersebut sehingga menimbulkan berbagai anasir mengenai siapa penyandang cacat yang dimaksudkan tersebut. Multi tafsirnya UU tersebut juga dikarenakan adanya kalimat "kendaraan khusus." Walupun sudah terdeskripsikan secara jelas mengani pengertiannya, tetapi dengan adanya kalimat tersebut menimbulkan simpulan-simpulan tersendiri yakni dengan adanya kalimat "kendaraan khusus" berarti hanya tuna daksa saja yang bisa memegang SIM ini dikarenakan yang mengendara dengan kendaraan khusus adalah penyandang tuna daksa. Simpulan lain menyebutkan bahwa "kendaraan khusus" tersebut tidak bisa dimaknai sempit bahwa tuna daksalah yang berhak, karena tuna rungu pun berdasarkan berbagai penelitian juga sudah seharusnya turut bisa mendapatkan haknya untuk bisa mendapatkan SIM. Sehingga disini menurut pendapat penulis seharunya pendefinisian penyandang cacat pada ketentuan umum dalam UU maupun dalam Perkap tersebut dimasukkan dengan jelas sehingga tidak ada pertanyaan lagi tentang apakah penyandang cacat dalam Pasal 80 huruf (e) UULLAJ dan Pasal 7 huruf (e) Perkap No. 9 Tahun 2012 itu hanya tuna daksa atau berlaku penyandang cacat lainnya yakni tuna rungu.

\section{Simpulan}

Satpas di Polda Metro Jaya Jakarta menafsirkan pasal 80 huruf (e) UULLAJ dan Pasal 7 huruf (e) Perkap No. 9 Tahun 2012 adalah dengan menafsirkan dengan menggunakan penafsiran secara $a$ contrario dan penafsiran Gramatikal. Satpas Polresta Denpasar menggunakan penafsiran teleologis dan penafsiran ekstensif untuk memaknai pasal tersebut. Sedangkan kebijakan Polresta Mojokerto Kota yang tidak menerbitkan SIM jenis apapun bagi pemohon dengan kondisi jasmani mengalami cacat pendengaran (tuna rungu) adalah karena adanya tafsiran restriktif.

Mengenai usulan penulis bisa bisa diberlakukan bagi pemohon tuna rungu, maka hendaknya dalam perubahan regulasi ataupun usulan adanya pedoman teknis bagi pemohon SIM harus ada kejelasan pendefinisian mengenai penyandang cacat yang dicantumkan dalam ketentuan undang undang atau 
perkap. Kalimat "kendaraan khusus" harusnya dijelaskan pula lebih lanjut mengenai hanya tuna daksa saja yang bisa memegang SIM ini dikarenakan yang mengendara dengan kendaraan khusus adalah penyandang tuna daksa.

\section{Daftar Pustaka}

Abdullah Z (2019) Deaf Grab drivers: 'They can do everything but hear'. Dalam: https://www.channelnewsasia.com/news/singapore/deaf-grab-drivers-they-can-do-everythingbut-hear-12126614. Diakses 2 Desember 2019.

Agustino L (2012) Dasar-Dasar Kebijakan Publik. Bandung: Alfabeta.

Alfredsson G (2002) The Usefulness of Human Rights for Democracy and Good Governance dalam Sano and G. Alfredsson (eds) Human Rights and Good Governance: Building Bridges. New York: Springer.

Golbran N (2010) Akses Terhadap Keadilan Penyandang Disabilitas Indonesia: Kajian Latar Belakang. Indonesia: Australian AID.

Infodatin (2014) Penyandang Disabilitas. Jakarta: Pusat Data dan Informasi Kementerian Kesehatan RI .

Jimly A (2006) Perihal Undang-Undang di Indonesia. Jakarta: Konstitusi Pers.

Rahardjo S (2006) Ilmu Hukum. Bandung: PT Citra Aditya Bakti.

Rofah (2011) Konsep Dasar Disabilitas dan Pendidikan Inklusif, Disabilitas dan Pendidikan Tinggi: Bunga Rampai Penelitian. Yogyakarta: Pusat Studi dan Layanan Difabel UIN Sunan Kalijaga UIN Sunan Kalijaga

Steinhardt D \& Wishart DE (2006) Driver and rider licensing provisions for clients who are deaf. Journal of the Australasian College of Road Safety 11 (s): 4-39.

Suharmini T (2009) Psikologi Anak Berkebutuhan Khusus. Yogyakarta: Kanwa Publisher.

Syafiie M (2014) Pemenuhan aksesibilitas bagi penyandang disabilitas. Inklusi 1 (2):269-290.

Tachjan (2006) Implementasi Kebijakan Publik. Bandung: AIPI.

Wiratama SM (2018) Pemenuhan Hak Penyandang Disabilitas Dalam Pelayanan Pembuatan Surat Izin Mengemudi (SIM) Di Kepolisian Resort Magetan. Skripsi. UII Yogjakarta. 